\title{
Family medicine internship support during the COVID-19 pandemic in Cape Town, South Africa - A narrative report
}

\begin{tabular}{|c|c|}
\hline $\begin{array}{l}\text { Authors: } \\
\text { Gaironesa Solc } \\
\text { Ayesha Allie } \\
\text { Raeesah Fakie } \\
\text { Daniel Tadmor } \\
\text { Kamaludin Asł } \\
\text { Colyn Le Roux } \\
\text { Junaid Omar } \\
\text { Mosedi Nama }\end{array}$ & $\begin{array}{l}\operatorname{mon}^{1} \text { (I) } \\
{ }^{1} \text { (D) } \\
\text { itiker }^{1} \text { (I) } \\
\text { (D) }\end{array}$ \\
\hline $\begin{array}{l}\text { Affiliations: } \\
{ }^{1} \text { Vanguard Cor } \\
\text { Centre, Metro } \\
\text { Services, West } \\
\text { Department o } \\
\text { Town, South A }\end{array}$ & $\begin{array}{l}\text { munity Health } \\
\text { Health } \\
\text { ern Cape } \\
\text { Health, Cape } \\
\text { frica }\end{array}$ \\
\hline \multicolumn{2}{|c|}{$\begin{array}{l}{ }^{2} \text { Division of Family Medicine, } \\
\text { Faculty of Health Sciences, } \\
\text { University of Cape Town, } \\
\text { Cape Town, South Africa }\end{array}$} \\
\hline \multicolumn{2}{|c|}{$\begin{array}{l}\text { Corresponding author: } \\
\text { Mosedi Namane, } \\
\text { mosedi.namane@uct.ac.za }\end{array}$} \\
\hline \multicolumn{2}{|c|}{$\begin{array}{l}\text { Dates: } \\
\text { Received: } 11 \text { July } 2020 \\
\text { Accepted: } 14 \text { Aug. } 2020 \\
\text { Published: } 06 \text { Nov. } 2020\end{array}$} \\
\hline \multicolumn{2}{|c|}{$\begin{array}{l}\text { How to cite this article: } \\
\text { Solomon G, Allie A, Fakier R, } \\
\text { et al. Family medicine } \\
\text { internship support during the } \\
\text { COVID-19 pandemic in Cape } \\
\text { Town, South Africa - A } \\
\text { narrative report. Afr J Prm } \\
\text { Health Care Fam Med. } \\
\text { 2020;12(1), a2661. https:// } \\
\text { doi.org/10.4102/phcfm. } \\
\text { v12i1.2661 }\end{array}$} \\
\hline \multicolumn{2}{|c|}{$\begin{array}{l}\text { Copyright: } \\
\text { (C) 2020. The Authors } \\
\text { Licensee: AOSIS. This } \\
\text { is licensed under the } \\
\text { Creative Commons } \\
\text { Attribution License. }\end{array}$} \\
\hline \multicolumn{2}{|l|}{ Read online: } \\
\hline asin: & $\begin{array}{l}\text { Scan this QR } \\
\text { code with your } \\
\text { smart phone or } \\
\text { mobile device } \\
\text { to read online. }\end{array}$ \\
\hline
\end{tabular}

The health-service redesign that came with the preparation for the surge of COVID-19 had a potential of disrupting the Family Medicine internship programme like it did to many other health and academic programmes. A team of Cape-Town based Community Health Centre (CHC) doctors mitigated this challenge by designing an innovative tool that facilitated ongoing supervision of the interns in order to achieve the outcomes of the Health Professions Council of South Africa (HPCSA).

Keywords: medical-interns; supervision; COVID-19; pandemic; Cape Town.

\section{Background}

In South Africa (SA), internship of newly qualified medical doctors is considered part of medical training. It is a 2-year post that is followed by 1-year community service before doctors can work independently as general practitioners or follow the stream of training further in a specialty of their choice. Both internship and community-service are compulsory and are remunerated. The supervision of SA-medical interns during a Family Medicine rotation is based on the premise that the accredited training platforms have the capacity to expose interns to a full package of primary care services within a community. ${ }^{1}$ This rotation spans 4 -months (inclusive of 1 month of psychiatry) within a total of 2 -year period of training. ${ }^{1}$ The interns are supervised to acquire core skills such as the management of undifferentiated illnesses. Our Community Health Centre ( $\mathrm{CHC}$ ) is an accredited 24-h urban-based training facility that provides free public-healthcare services to the surrounding communities of poor socioeconomic status.

The COVID-19 surge became apparent in SA in March 2020. It necessitated significant serviceredesign and a massive de-escalation of 'non-essential' services, for the purpose of increasing the capacity to manage patients and to improve infection control.

COVID-19 pandemic not with standing, a cadre of competent primary care clinicians is still going to be required to support the journey of SA towards Healthcare $2030^{2}$ and Universal Health Coverage. ${ }^{3}$ This is what motivated our team of doctors (authors of this report) to innovate a system that would limit supervision deficiencies as was found by Bola et al. ${ }^{4}$

\section{Innovation}

A team comprising of medical officers (experienced in rendering primary care), communityservice doctors (who completed their internship at the end of 2019) and a Family Physician (well-versed in the primary-healthcare approach) participated in the development of the Vanguard Supervision Tool for Medical Interns (VaSTMI-COV19) using a modified Delphi approach. This approach is a communication process of experts over multiple rounds of deliberations, which allows them to reach a consensus about a framework they are developing. The participants started the process by examining the Health Professions Council of South Africa (HPCSA) logbook for the desired outcomes of training. ${ }^{1}$ This was followed by several rounds of discussions taking place in the month of April 2020 to refine a table that matched core-objectives of training with required skills and appropriate methods of supervision until a consensus was reached. Infection Prevention Control (IPC) and Occupational Health and Safety (OHS) training and practice were included. The interns were given an opportunity to 
TABLE 1: Vanguard supervision tool for medical interns during covid-19 pandemic (vastmi-COVID-19).

\begin{tabular}{|c|c|c|}
\hline Supervision method & HPCSA objectives & Skills to be gained \\
\hline $\begin{array}{l}\text { Orientation } \\
\text { (by clinical manager) }\end{array}$ & $\begin{array}{l}\text { Understand the district health system and its components } \\
\text { (facility-based services, home- and community-based care } \\
\text { services, healthcare teams, referral pathways, stakeholders, } \\
\text { support systems) } \\
\text { Staff-safety matters }\end{array}$ & $\begin{array}{l}\text { Understand comprehensive healthcare. } \\
\text { Understand continuation of care. } \\
\text { Understand continuum of care. } \\
\text { Know the community served. }\end{array}$ \\
\hline $\begin{array}{l}\text { Teamwork } \\
\text { (Learning conversations) }\end{array}$ & Management of emergencies. & $\begin{array}{l}\text { Reflect on experience } \\
\text { Appreciate own role in the team. } \\
\text { Understand clinical forensic medicine at the primary level. }\end{array}$ \\
\hline $\begin{array}{l}\text { Daily 'opportunistic' teaching } \\
\text { (by attending supervisor) }\end{array}$ & $\begin{array}{l}\text { Management of 'walk-in' patients. } \\
\text { Rational prescribing of medication. Rational use of } \\
\text { investigations. }\end{array}$ & $\begin{array}{l}\text { Management of undifferentiated problems. } \\
\text { Learn cost-effective approach. } \\
\text { Writing of legal prescriptions } \\
\text { Reporting of adverse-drug reactions. }\end{array}$ \\
\hline $\begin{array}{l}\text { Quizzes } \\
\text { (During scheduled times) }\end{array}$ & $\begin{array}{l}\text { Interpretation of ECGs, X-rays and laboratory investigations. } \\
\text { Pattern recognition and management of common conditions, } \\
\text { for example, eczema. }\end{array}$ & $\begin{array}{l}\text { To integrate skills, knowledge and experiences gained in other } \\
\text { domains of internship placement or in prior learning as a medical } \\
\text { student. }\end{array}$ \\
\hline $\begin{array}{l}\text { Video-based teaching } \\
\text { (Promote remote learning to enhance and } \\
\text { complement practical training) }\end{array}$ & $\begin{array}{l}\text { Videos identified include: } \\
\text { How to suture. } \\
\text { How to insert an intercostal drain. } \\
\text { 'Donning' and 'Doffing' of *PPE. }\end{array}$ & $\begin{array}{l}\text { Gain competence in: } \\
\text { common procedural skills. } \\
\text { COVID-19 related IPC and OHS. }\end{array}$ \\
\hline $\begin{array}{l}\text { Attend discussions of new policies, } \\
\text { circulars and guidelines } \\
\text { (led by senior doctors) }\end{array}$ & $\begin{array}{l}\text { Participate in evolving clinical practice based on new policies, } \\
\text { circulars and guidelines. }\end{array}$ & Evidence-based practice. \\
\hline $\begin{array}{l}\text { Ethical discussions } \\
\text { (Learning opportunities provided by } \\
\text { COVID-19) }\end{array}$ & $\begin{array}{l}\text { Obtaining informed consent. } \\
\text { Respect for confidentiality. } \\
\text { Respect for the dignity of persons/autonomy. } \\
\text { Promote social justice. } \\
\text { Withholding or withdrawing treatment. }\end{array}$ & $\begin{array}{l}\text { Develop sensitivity for ethical issues, cultural differences and } \\
\text { human rights. } \\
\text { Promote 'living' the Western Cape Government's }{ }^{*} C^{2} A I R^{2} \text { values. }\end{array}$ \\
\hline $\begin{array}{l}\text { Role playing } \\
\text { (Led by senior doctor) }\end{array}$ & $\begin{array}{l}\text { Motivational interviewing for behaviour change. } \\
\text { Breaking bad news. } \\
\text { Holding a family conference. }\end{array}$ & Develop communication and counselling skills. \\
\hline $\begin{array}{l}\text { Debriefing following resuscitations } \\
\text { (either post- emergency unit calls or during } \\
{ }^{*} M \& M \text { meetings) }\end{array}$ & $\begin{array}{l}\text { Approach to: } \\
\text { Adult and paediatric resuscitations. } \\
\text { Adult cardiac arrest. - A shocked child/convulsing child/child } \\
\text { with breathing difficulties. } \\
\text { Managing a hypoxic PUI/ COVID-19 patient }\end{array}$ & $\begin{array}{l}\text { Gain competency in emergency-care skills. } \\
\text { Learn how to address gaps identified in *M\&M meetings. } \\
\text { See the value of debriefing on mental health. }\end{array}$ \\
\hline $\begin{array}{l}\text { Folder audits } \\
\text { (use provincial and national audit tools) }\end{array}$ & $\begin{array}{l}\text { Rational use of antibiotics. Record keeping according to } \\
\text { national core standards. }\end{array}$ & $\begin{array}{l}\text { Promote: } \\
\text { antibiotic stewardship } \\
\text { proper documentation } \\
\text { auditing }\end{array}$ \\
\hline
\end{tabular}

M\&M, morbidity \& mortality; PUI, person under investigation or suspect for COVID-19; PPE, personal protective equipment; $\mathrm{C}^{2} A \mathrm{R}^{2}$, caring, competence, accountability, integrity, responsiveness and respect.

comment on the contents of the table and where necessary, adjustments were made. May 2020 served as a pilot and implementation month.

\section{Conclusion}

Feedback from interns suggests that this alternative supervision method is enjoyable, promotes supportive relations between interns and supervisors and creates opportunities to learn from each other. Regarding supervisors, we observed some of their previously unknown strengths emerging organically during VaSTMI-COV19 led processes, with one colleague, for example, ending-up as a 'natural' training co-ordinator and another as an information-technology 'consultant'. The Covid-19 pandemic has afforded all healthcare workers to learn and 'figure out' new things together that are related to the pandemic, and the training tool facilitated that interns be part of that experience. A formal qualitative study will be required to assess whether this tool is able to produce 'good interns' with attributes described by De Villiers et al. ${ }^{5}$ We are hopeful that this tool will serve as a template that can be adjusted by others for use in their setting during this pandemic and perhaps beyond.

\section{Acknowledgements}

During the pilot phase, the tool was tested on the following Family-medicine interns (with interns giving feedback on the process and content): Timothy Adam, Jessica Barell, Nina Barell, Lina Hahle, Zahra Logday, Sambesini Mfenyana, Olga Lombard and Kayla Marshall.

\section{Competing interests}

The authors have declared that no competing interest exists.

\section{Authors' contributions}

All authors contributed equally to this work.

\section{Ethical consideration}

This article followed all ethical standards for a research study without a direct contact with human or animal subjects. 


\section{Funding information}

This research received no specific grant from any funding agency in the public, commercial or not-for-profit sectors.

\section{Data availability statement}

Data sharing is not applicable to this article as no new data were created or analysed in this study.

\section{Disclaimer}

The views and opinions expressed in this article are those of the authors and do not necessarily reflect the policy or position of any affiliated agency of the authors.

\section{References}

1. Health Professions Council of South Africa. Medical and Dental Professions Board's Handbook on Internship Training [homepage on the Internet]. 2017 [cited 2020 Mar 03]; p. 32. Available from: https://www.hpcsa-blogs.co.za/wp-content/ uploads/2017/04/2017-IN-Handbook-Part-I-and-II.pdf\%0D

2. Department of Health,Western Cape Province SA. Healthcare 2030: The road to wellness [homepage on the Internet]. 2014 [cited 2020 Apr 03]; p. 2-38. Available from: https://www.westerncape.gov.za/assets/departments/health/ healthcare2030.pdf

3. Rispel LC, Shisana O, Dhai A, et al. Achieving high-quality and accountable universal health coverage in South Africa: A synopsis of the Lancet National Commission Report. South African Health Report; 2019.

4. Bola S,Trollip E, Parkinson F. The state of South African internships: A national survey against HPCSA guidelines. South African Med J. 2015;105(7):535-539. https://doi.org/10.7196/SAMJnew.7923

5. De Villiers M, Van Heerden B, Van Schalkwyk S. 'Going the extra mile': Supervisors' perspectives on what makes a 'good' intern. South African Med J. 2018;108(10):852-857. https://doi.org/10.7196/SAMJ.2018.v108i10.13052 